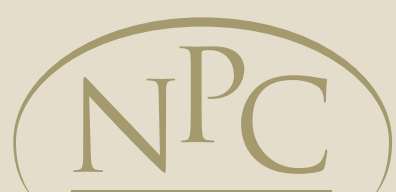

NATIONAL POVERTY CENTER

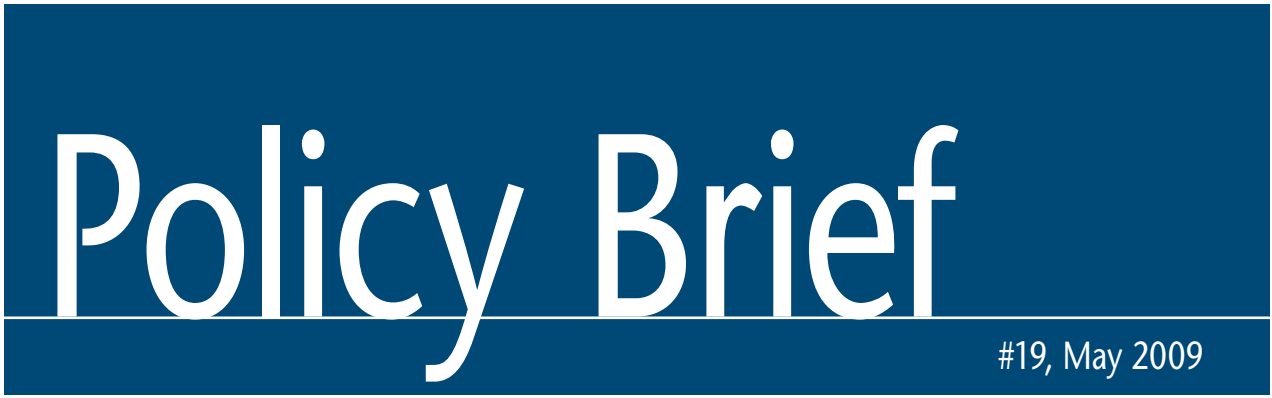

\title{
The Price of Independence: The Economics of Early Adulthood
}

Highlights from the edited volume, The Price of Independence, Sheldon Danziger and Cecilia Elena Rouse, eds. The volume can be ordered from the Russell Sage Foundation: https://www.russellsage.org/publications/books/070723.278613

The National Poverty Center's Policy Brief series summarizes key academic research findings, highlighting implications for policy.

The NPC encourages the dissemination of this publication and grants full reproduction right to any party so long as proper credit is granted the NPC. Sample citation: "Title, National Poverty Center Policy Brief \#x".
Who is an "adult?" Compared to their parents' generation, the typical markerscompleting schooling, working, living independently, marrying and having children-are occurring later, and in a less traditional order for today's young adults.

Many have speculated as to what has made the transition to adulthood more complex and variable. Everything from improved health and increased life expectancy to smaller family size to the rising cost of housing have been offered as explanations. Though many cite economic changes as causal factors, few have provided strong empirical evidence. Establishing a causal relationship between economic conditions and the lengthening transition to adulthood is difficult, because social norms have also changed. The eleven chapters in The Price of Independence, a volume sponsored by the Research Network on Transitions to Adulthood, present findings on what we do and do not know about the interplay between economic changes and changes in the transition to adulthood.

\section{Findings}

+ Between 1960 and 2004, the median age at first marriage in the U.S. had risen from about 20 to 26 for women, and from 23 to 27 for men. The gender age gap in first marriage has never been smaller.

+ Between 1969 and 2004, young women entered the labor force in increasing numbers and worked more hours. As a result, there was a dramatic decrease-from roughly $80 \%$ to less than $50 \%$-in the percentage of women in their early 30 s earning less than the federal poverty line for a family of four. The news is not so good for men. In 1969 only about I0\% of men in their early 30 s earned this little, but in 2004 nearly a quarter did.

- Though more students are graduating from college, it is taking them longer to do so. Among high school graduates born in $1950,15 \%$ had received a bachelor's degree by the age of 22; among those born in 1970, only $12 \%$ had. By the age of 28 , however, $28 \%$ of those born in 1970 had graduated, compared to $25 \%$ of those born in 1950 .

+ The high cost of housing and high rates of debt are often cited as reasons today's young people are having trouble establishing independence. However, the debt to net-worth ratio for young adults remained at 0.57 in both 1963 and 2001, and inflation adjusted median monthly rents increased by only $\$ 15$ between 1980 and 2000 .

- That young adults are taking longer to transition from parental dependence to economic self-sufficiency is not just an American phenomenon. The same trend has occurred in many other industrialized countries. 


\section{Marriage Trends}

Marriage has always been a key marker of adulthood. In recent years, young adults, especially young women, are postponing marriage. The median age at first marriage for both men and women followed a

U-shaped pattern over the 20 th century. At the turn of the century, the median age at first marriage was about 22 for women and 26 for men. During the 1950 s this dropped to about 20 for women and 23 for men. Since I960 there has been a continuous increase in the age at first marriage for both men and women. By 2004, the gender gap was less than two years - the median age at first marriage was about 26 for women, and not quite 28 for men-down from a gap of about four years at the beginning of the century.

Delayed marriage has been accompanied by both a delay in childbearing and an increase in the percentage of births occurring outside of marriage. Less than $20 \%$ of women born between 1925 and I950 were childless at the age of 35 . Among those born between 1965 and 1970, 50\% of 35 year-old white women are, as are roughly $30 \%$ of 35 year-old African American and Hispanic women (Wu and $\mathrm{Li} 2005$ ). There has also been a large increase in the number of women who are not only childless, but have never married by age 35 . For women born between 1965 and 1970, these percentages are $27.3 \%$ for whites, $23.9 \%$ for blacks and $16.6 \%$ for Hispanics. At the same time that women overall are delaying marriage and childbearing, some are delaying marriage, but not childbearing. The proportion of all births to unmarried women increased from $5 \%$ in 1960 to $37 \%$ in 2005 (Child Trends 2007).

\section{Securing Employment}

A key economic outcome in the transition to adulthood is the achievement of stable employment. It is taking young men today longer to earn enough money to support a family than it used to. In 1969, only about $10 \%$ of men in their early 30 s could be classified as low earners (earning less than the federal poverty line for a family of 4). However, because of falling real wages and employment for young men without a college degree, by $200423 \%$ were. In contrast, during this same period, a decreasing percentage of women earned too little to support a family. In 1969, $75-80 \%$ of women between the ages of 21 and 35 were low earners. In 2004, 75-80\% of young women ages 2I to 24 were low earners, but no more than $50 \%$ of women in their 30 s were.

Lisa Bell, Gary Burtless, Janet Gornick and Timothy Smeeding (chapter 2) document that the transition of young adults from parental dependence to economic selfsufficiency is taking longer not only in the U.S., but in other industrialized countries as well. In all six countries studied (the US, Canada, the UK, Italy, Germany and Belgium) since the 1980 s, the relative earnings of young adults (under 25) have declined in comparison to earnings of older workers, in relation to the income required to support an independent household, and compared to 20 years ago. At the same time, women over the age of 25 have achieved economic gains.

Employment instability provides another dimension of the economic difficulties facing young workers. In the quarter century following World War II, much attention focused on the "company man" who spent his whole career with a single employer. Today's workers are now much more likely to move from firm to firm-in part to take advantage of new opportunities, but also because of involuntary lay-offs and plant closings.

\section{Figure. Percentage of Young People (18-34) Living with Their Parents, Without a Partner or Child}

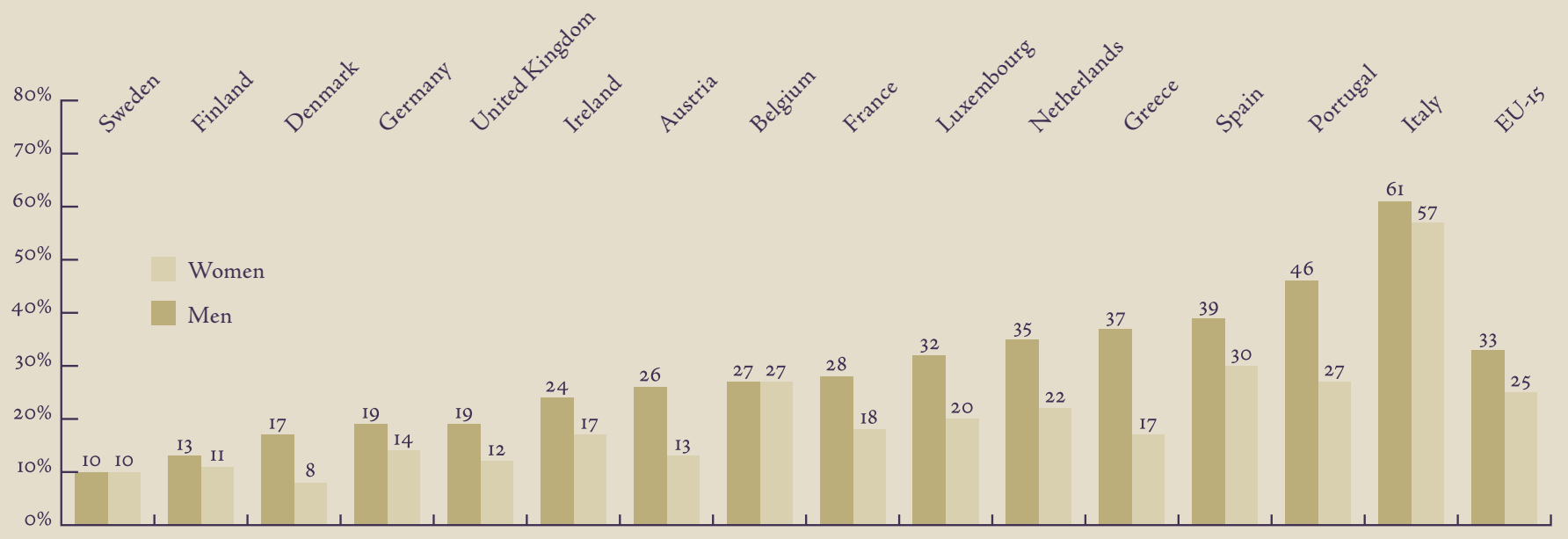

Source: Newman and Aptekar, Chapter 8 in The Price of Independence 
Henry Farber (chapter 3) finds that, at any age, the amount of time male workers have spent with their current employer has fallen. In 1973, about 50\% of employed men between the ages of 35 and 64 had been with their current employer for at least ten years. By 2006 fewer than $40 \%$ had. For women, the incidence of such tenure increased slightly from 30 to $34 \%$, due partly to the fact that more women, especially those with young children are staying in the work force.

Health insurance coverage, often viewed as a marker of a "good" job, is addressed in chapter 4 by Helen Levy, who finds that young adults are the most likely to be uninsured. In part this is because public coverage ends at age I8, as does parents' employer-provided coverage if the child is no longer a student. In 1988, $42 \%$ of young adults (18-34) had employer-subsidized health insurance. That proportion had fallen to $34 \%$ in 2005 . During the same period, the portion of young adults that were uninsured rose from 2 I to $28 \%$. Such indirect evidence suggests young people are having difficulty obtaining stable, quality jobs.

\section{Completing Schooling}

Another precursor to reaching adulthood is completing one's education. Traditionally young people, particularly men, chose to marry and have children only after completing their educations and achieving economic independence. One explanation for why young people are taking longer to find stable employment is that more of them, particularly women, are attending college, and it is taking longer to complete a degree. While $15 \%$ of high school graduates born in 1950 had received a bachelor's degree by the age of 22 , only $12 \%$ of those born in 1970 had. But by age $28,28 \%$ of the 1970 cohort had graduated, while just $25 \%$ of the 1950 cohort had. Over the past several decades, the rate of college enrollment stayed roughly the same for men, but increased dramatically for women. Women are now more educated than men.

In chapter 5, Maria Fitzpatrick and Sarah Turner show that the median time it takes to complete an undergraduate degree has increased from four to five years, and about one quarter of all students now take more than six years. Federal financing programs, such as Pell Grants and Stafford loans, as well as universities' policies regarding part-time students, have allowed more flexibility with regard to combining work and/or parenting with school. As a result, the proportion of college students who are "college age" (I8 to 2I) has decreased from 74 to $56 \%$ over the last three decades.

\section{Living Arrangements}

One aspect of the delayed transition to adulthood that has captured the attention of the media, as well as many parents, is the increased likelihood that young adults live at home. This trend is evident in both the United States and Europe. In the U.S. the most striking trend among unmarried young adults is the greater percentage that are living either on their own or with a person other than a spouse. Over the past 40 years, the percentage of women aged 19 to 24 living with a spouse declined from 57 to $22.5 \%$ while those living on their own or with other (unrelated) persons increased from 17 to $42.5 \%$. Those living with a parent increased from 26 to $35 \%$ (Matsudaira 2006).

The age of departure from the parental home has increased in all developed countries. Katherine Newman and Sofya Aptekar (chapter 8) hypothesize that differences across countries in housing market conditions, labor market conditions, and social welfare programs account for cross-country differences in living arrangements. For example, countries, such as Sweden, which provide housing subsidies widely, have more youths living independently than countries that do not provide them, such as Italy (see figure).

In chapter 6, Carolyn Hill and Harry Holzer analyze the effects of labor-market experience on the living arrangements of two cohorts of 20 to 22 year old Americans. In $1985,46 \%$ of this age group lived with their parents; in 2003, 57\% did. While they find that those with relatively high earnings at this age are somewhat less likely to live with their parents than are those with relatively low earnings, they conclude that labor market changes can explain only a small part of the recent trends in living arrangements and marriage rates.

If labor market opportunities are not the primary factor in the lengthening time that children live with their parents, perhaps unaffordable housing or debt is to blame. Aaron Yelowitz (chapter 7) analyzes the costs of homeownership and rents, and finds that between 1980 and 2000 the inflation-adjusted median monthly housing payment actually fell from \$1476 to \$1092, due in part to the emergence of historically low interest rates. Over the same period, the median monthly rent increased only slightly, from \$726 to \$74I. Yelowitz does find, however, that when home prices rise in a metro area, the percentage of young adults who live independently declines. However, this can explain only a small part of the total decline in independent living between 1980 and 2000 .

The idea that young people may be having trouble establishing independent households due to the heavy burden of college and credit card debt is addressed by Ngina Chiteji in chapter 9. In examining the extent and composition of debt over the last four decades, today's young adult heads of household (aged 25-34) do not appear overly burdened. Between 1963 and 200I, mean total debt increased from $\$ 26,562$ to $\$ 55,616$ (in constant 200I dollars), but mean 
net worth rose as well, leaving the debt-tonet worth ratio at 0.57 in both years. Mean education debt in 2001 was less than $\$ 3500$ per household. Chiteji concludes that only about $15 \%$ of young adult households would be unable to off their debts with their current assets.

\section{Family Background}

Two other factors that may have contributed to the lengthening transition to adulthood are differences in family background and increased incarceration rates. Melanie Guldi, Marianne Page and Ann Huff Stevens (chapter Io) compare two cohorts: those who came of age in the mid-r97os and the early-199os. Those whose parents completed college are more likely to do so themselves, and are also less likely to have started families by the age of 30 . However, the effects of family background differences have not changed much over time.

Being incarcerated early in one's life delays the achievement of conventional markers of adulthood. Newly released offenders have difficulty obtaining employment, have little savings, and are barred from receiving many types of public assistance. Between 1977 and 2004, the proportion of men who were either currently in prison or had a record roughly doubled, from 2.3 to $4.9 \%$; for black men, the percentage increased from 8.7 to $16.6 \%$. Stephen Raphael, in chapter II, finds that men who have been incarcerated are less likely to marry, more likely to live with their parents, work fewer weeks per year, and earn less when they do work than do similar men who have not been incarcerated.

\section{Summary}

The chapters in this volume document that it is taking young men longer than it did in the past to secure well-paying, stable jobs that allow them to support a family. In contrast, because their educational attainment, employment and earnings have increased relative to those of young men, young women are better able to support themselves, even though their economic status continues to lag that of men. Many have argued that decreased employment prospects, lower wages, higher housing prices and increased debt have made it more difficult for young people, particularly men, to assume the responsibilities that have traditionally been associated with adulthood. Taken together, the chapters in this volume suggest a limited role for such economic factors in explaining recent trends.

The delayed transition to adulthood observed in the United States and most industrialized countries over the past several decades has more likely been caused by changes in the social norms of young people, their parents, and society as a whole regarding female labor force participation, marriage and childbearing, and combining schooling with work and family roles.

\section{References}

Child Trends. 2007. "Percentage of Births to Unmarried Women." Accessed at $w w w$. childtrendsdatabank.org/pdf/75_DF.pdf.

Matsudaira, Jordan D. 2006. "Economic

Conditions and the Living Arrangements of Young Adults." Network on Transitions to adulthood working paper (May).

Accessed at www.transad.pop.upenn.edu/ downloads/matsudaira.pdf.

Wu, Lawrence L., and Jui-Chung Allen Li. 2005. "Historical Roots of Family Diversity: Marital and Childbearing Trajectories of American Women." In On the Frontier of Adulthood: Theory, Research, and Public Policy, edited by Richard A. Settersten Jr, Frank F. Furstenberg Jr., and Rubén G. Rumbaut. Chicago, Ill.: University of Chicago Press.

\section{About the Authors}

Sheldon Danziger is Henry J. Meyer

Distinguished Professor of Public Policy and

Director of the National Poverty Center at

the Gerald R. Ford School of Public Policy at the University of Michigan, and a member of the Research Network on Transitions to Adulthood of the John D. and Catherine T. MacArthur Foundation.

\section{Cecilia Elena Rouse is Theodore A. Wells}

'29 Professor of Economics and Public

Affairs at Princeton University, Director of

the Princeton Education Research Section, and a member of the Research Network on Transitions to Adulthood of the John D. and Catherine T. MacArthur Foundation.

\section{Major funding for the National Poverty Center is provided by the Office of the Assistant Secretary for Planning and Evaluation, U.S. Department of Health and Human Services.}

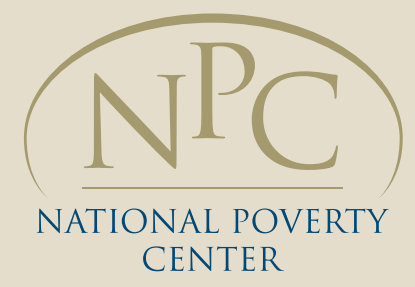

National Poverty Center

Gerald R. Ford School of Public Policy

University of Michigan 735 S. State Street

Ann Arbor, MI 48109-309I

734-6I5-53I2

npcinfo@umich.edu 